\title{
EL THEOPHRASTUS REDIVIVUS Y LA ETERNIDAD DEL MUNDO
}

\section{THEOPHRASTUS REDIVIVUS AND THE ETERNITY OF THE WORLD}

\author{
Marcelino Rodríguez Donís" \\ Universidad de Sevilla
}

Resumen: El anónimo autor del manuscrito latino Theophrastus redivivus, de la segunda mitad del siglo XVII, sostiene la tesis de la eternidad del mundo frente a los partidarios del creacionismo, inspirados en Moisés. Después de señalar las contradicciones internas del Génesis y su contraste con el Eclesiastés, hace un exhaustivo recorrido histórico sobre las diferentes opiniones de los filósofos grecolatinos acerca de si el mundo ha tenido un origen o no, decantándose a favor de la tesis de la eternidad del mundo, de acuerdo con el aristotelismo renacentista en la vía de Pomponazzi. Pero no sólo se inspira en Aristóteles, sino que también sigue a Epicuro, sin hacer hincapié, curiosamente, en que éste, como todos los atomistas, no es partidario de la eternidad del mundo. Asimismo, expone los argumentos acerca de la eternidad del mundo de Ocelo de Lucania y de Filón de Alejandría, judío fiel a las enseñanzas de Moisés, que en De aeternitate mundi defiende la inengendrabilidad e indestructibilidad del mundo.

Palabras clave: eternidad, creación, tiempo, lugar, movimiento, principios, materia, religión, probabilidad, verosimilitud, orden, azar.

ABstRACT: The anonymous author of the Latin manuscript Theophrastus redivivus (from the second half of the 17th century) upheld the thesis of the eternity of the world against the supporters of creationism inspired by Moses. After pointing out the internal contradictions of Genesis and its contrast with Ecclesiastes, he carried out an exhaustive historical study, focusing on the different views of the Greco-Roman philosophers about whether the world had an origin or not. Finally, he opted for supporting the view of the eternity of world, following Pomponazzi's interpretation of Renaissance Aristotelianism. The anonymous author was not only inspired by Aristotle, but also followed Epicurus,

\footnotetext{
"Email: mrdonis@ub.es.
} 
without emphasizing, surprisingly, that, like all the atomists, Epicurus was not in favour of the eternity of the world. Theophrastus redivivus al so sets forth arguments about the eternity of the world taken from other philosophers such as Ocellus Lucanus and Philo of Alexandria, a Jewish philosopher faithful to the teachings of Moses, who in his De aeternitate mundi argued that the word is neither generable nor perishable.

Keywords: Eternity, Creation, Time, Space, Movement, Principles, Matter, Religion, Probability, Verisimilitude, Order, Chance.

\section{Introducción al problema}

Aunque el anónimo autor del manuscrito latino Theophrastus redivivus dice expresamente que está escribiendo su obra en 1659, su pensamiento se fundamenta en los autores clásicos grecolatinos y en las grandes figuras del Renacimiento: Maquiavelo, Bodin, Pomponazzi, Cardano, Vanini, Campanella, Escaligero, Olivarius, Galeotto Marzo, Magius, Rhodigino etc. No hay en su obra manuscrita el menor rastro de la filosofía de Descartes o Gassendi y solo cita de entre sus coetáneos a Saumasius, Patin, Cyrano, y a algún otro.

La primera y única edición crítica del manuscrito latino Theophrastus redivivus, a cargo de Guido Canziani y Gianni Paganini, se basa en la copia del manuscrito W (Wien), cod. 11.451 (Rec. 452) de la Nationalbibliotek de Viena, que tiene setecientas páginas numeradas ${ }^{1}$. En la actualidad se conocen cuatro copias del manuscrito, que fue celosamente ocultado y permaneció inédito, probablemente porque representaba un desafío directo y frontal a la doctrina oficial de la Iglesia. Hasta el primer tercio del siglo XX muy pocos sabían de su existencia. En efecto, Ira O. Wade ${ }^{2}$, aun advirtiendo que aparecía frecuentemente citado en algunas obras de la literatura clandestina del siglo XVIII, lo daba por desaparecido. J. S. Spink ${ }^{3}$, indagando en los fondos latinos de la Biblioteca Nacional de Paris, se encuentra con el manuscrito 9324, de mil noventa páginas. A partir de ese momento, el Theophrastus redivivus vuelve realmente a la vida. En él están contenidas, dice Spink, las principales ideas de la filosofía de la izquierda. Estamos, según él, ante un vivero de propaganda antirreligiosa donde los no creyentes

\footnotetext{
1 Theophrastus redivivus (1981). En lo sucesivo utilizaremos la abreviatura Tr. Advertimos al lector de que el anónimo escribe deum, solem, lunam (sic), con minúscula. Nosotros lo haremos con mayúscula por razones de uniformidad.

2 WADE (1938).

3 SPINK (1937).
} 
se encontrarán a placer. Algunos creen que la obra es un centón. Henri Busson lo considera un libro "vieux à sa naissance» ${ }^{4} \mathrm{y}$ cree que su autor permaneció aislado y ajeno a la filosofía de su época; da la impresión de que su pensamiento está «en dehors du temps» y ha sido sacado de los libros antiguos. Réné Pintard se refiere a él diciendo que es autor de la obra más impía de su tiempo («l'auteur de l'oeuvre plus impie composée alors») y que es un compilador más que un creador («il compile plus qu'il ne crée»), ajeno a los problemas y trabajos contemporáneos Sus lecturas se centraban, según Pintard, en el Heptaplomeres de Bodin y en el Amphitheatrum de Vanini 5 .

En el frontispicio de la obra, aparece el Theophrastus redivivus junto a los principales representantes de la incredulidad (Protágoras, Diágoras, Teodoro de Cirene, Teofrasto de Ereso, su patrono, Platón, Epicuro, Cicerón, Plinio, Galeno, Aristóteles, Lucrecio, Séneca, Luciano y Sexto Empírico) bajo esta leyenda: «Hi omnes negaverunt Dominum et dixerunt: Non est Ipse».

El primer estudio en profundidad sobre el Theophrastus redivivus es el de Tullio Gregory ${ }^{6}$, que utiliza la copia del manuscrito de la Biblioteca Nacional de Paris, conocido como manuscrito $\mathrm{P}$, de mil noventa páginas. El autor, con un dominio magistral de las fuentes renacentistas y de los entresijos de la crítica de la ortodoxia eclesiástica al ateísmo, hace un recorrido por los seis tratados de que se compone la obra, interesándose fundamentalmente por los problemas religiosos y sociopolíticos. Para él, el Theophrastus redivivus es una obra clara, sistemática, apertamente materialistica e ateistica, asentada en una nueva lectura de los textos filosóficos antiguos, que suministra los presupuestos de una filosofía libre y atea que «el pensamiento libertino había venido preparando con extrema cautela y sutiles argumentos» ${ }^{7}$. También señala la tendenziosità del anónimo al pretender que los demás filósofos estarían de acuerdo con lo que él dice de ellos. El libro de Gregory, según manifiestan los autores de la edición crítica del Theophrastus redivivus, fue el detonante que les llevó a acometer la inmensa tarea de la publicación del texto latino.

Los autores de la edición crítica del Theophrastus redivivus, en la Introducción, describen las características de los cuatro manuscritos (W, H, P y L) que

${ }^{4}$ Busson (1948), pp. 186-187.

5 Pintard (1943), vol. I, pp. 433, 644.

${ }^{6}$ Gregory (1979).

7 Ibid., p. 11. 
hoy se conocen, así como las relaciones que hay entre ellos. También aparecen abordadas estas cuestiones en mi libro Materialismo y ateísmo. La filosofía de un libertino del siglo $X V I I^{8}$, donde se exponen en detalle los argumentos en que se sustentaba la crítica de la ortodoxia católica (representada, de modo principal, por Lesius, Garasse y Mersenne) a los filósofos que ella misma denominaba libertinos: Charrón, Maquiavelo, Bodin, Bruno, Cardano, Campanella, Vanini, B. des Périers, etc., que son, justamente, el núcleo, junto con los autores antiguos, de la filosofía del Theophrastus redivivus.

El término libertino se utilizaba en diferentes sentidos, pero fundamentalmente para referirse a los que no aceptaban la doctrina de la Iglesia, bien fuera en el terreno del dogma o en el de la moral o en ambos. Por eso se habla de un libertinismo erudito y de un libertinismo de costumbres. Mersenne, uno de los máximos representantes de la ortodoxia, consideraba heréticas muchas de las tesis de Maquiavelo, Charron, Bodin, Bruno, Pomponazzi, Cardano y Vanini en materia de religión: todos estos autores, dice, «avoient l'esprit extravagante et ne respiroient rien que libertinage et impieté)»?

El objetivo que se propone el anónimo autor del Theophrastus redivivus es, en esencia, retomar el pensamiento de los libertinos, criticados por la ortodoxia católica, y demostrar que, desde la perspectiva de la filosofía basada en la razón natural y no en la fe, son verdaderas las tesis consideradas falsas por la Iglesia. Escribe su libro, según dice en el prólogo, para que los teólogos puedan refutar, al tenerlas reunidas en un solo tratado, más fácilmente las doctrinas contrarias a la filosofía cristiana defendidas por los libertinos: que Dios no existe, que el mundo no es eterno, que el alma es mortal, que los infiernos son una fábula, que la religión es arte política, que la muerte debe ser despreciada, ya que no hay otra vida, y que el placer es el único bien del hombre ${ }^{10}$.

Hemos de tener en cuenta que una cosa es lo que dice en el texto y otra lo que afirma en el paratexto, es decir, en el prólogo, en la peroratio ad fideles et vere sapientes religionis christianae sectatores y en la peroratio operis ad sapientes saeculi. En efecto, en el prólogo de la obra, advierte a sus lectores de que si en

8 Rodríguez Donís (2008).

9 Mersenne (1624), p. 211.

10 Tr, p. 8: «Ex antiquorum aliorum philosophorum sententia deum non esse referam, mundumque aeternum, animam mortalem, inferos fabulosos, religionem artem politicam et astutorum commentum; mortem item esse contemnendam, tamquam ab illa nihil superfuturum, vitae insuper voluptuose operam dare hilariterque genio indulgere, solum esse hominis bonum». 
su libro hay afirmaciones contrarias a nuestra religión, no son suyas y que él se limita, ya que es un cristiano fiel a Roma, a exponer las enseñanzas extraídas del pensamiento de los filósofos ${ }^{11}$.

El autor dice haber compuesto este «compendio de todos los males y venenos para que los teólogos puedan disponer de los remedios y antídotos aptos e idóneos para cada mal y para que puedan luchar con iguales armas contra los filósofos. Antes lo han intentado, pero unos solo con argumentos basados en la autoridad de la fe y otros solo con descalificaciones, no con argumentos naturales como los filósofos, pues en las pruebas de todos misterios de la religión, parten de un principio destruido y demolido por la filosofía: que Dios existe» ${ }^{12}$. Si emplean argumentos basados solo en la razón natural y prescinden de las descalificaciones, con la ayuda del cielo, los teólogos podrán sacar del error y conducir a una vía más recta a los sabios del mundo, que hoy son aún una ingente multitud ${ }^{13}$.

Para el anónimo solo son verdaderos filósofos los ateos y todas las grandes figuras de la filosofía (Platón, Aristóteles, Epicuro, Séneca, Averroes, etc.), quienes, aunque hablen de los dioses, lo hacen para no ser perseguidos, es decir, por miedo. Las creencias religiosas pueden, según él, ser útiles pero no verdaderas ni demostrables. Si se pudiesen demostrar no serían objeto de fe, sino un conocimiento cierto y evidente, imposible acerca de estas cosas ${ }^{14}$. La existencia de Dios, la creación del mundo a partir de la nada, que la religión sea entregada y enseñada por Dios y no fruto de la astucia de los gobernantes, la inmortalidad del alma y la existencia del Paraíso y de los Infiernos, no se pueden demostrar con la razón natural, a pesar de que algunos teologastros digan lo contrario ${ }^{15}$.

El anónimo se propone, según dice, componer un tratado en el que se recojan las sentencias y opiniones de los filósofos sobre los dioses, imitando a Teofrasto de Ereso (de ahí el título de la obra), que había escrito, según nos dice Diógenes Laercio (Vidas de los filósofos, V, 2), en seis libros, una historia de lo que

${ }_{11} \mathrm{Tr}$, ibidem: «Si quae vero in hoc opere meo sunt, quae a nostrae religionis mente abhorrere videantur, sciant, monitosque velim omnes qui legerint, haec non tamquam mea, sed ex philosophorum mente me addidissem!.

$12 \mathrm{Tr}$, p. 7.

13 Ibidem.

14 Tr, p. 927.

15 Ibidem: «deum esse, mumdum ab illo ex nihilo creatum, religionem ab illo esse traditam atque praeceptam, animam esse immortalem, sola religionis fide constare, non vero naturali ratione, quidquid garriant theologastri quidam, qui ratione et humano discursu atque intelligentia haec se demonstrare praesumunt, et comprendí posse afirmant». 
se dice sobre los dioses que no ha llegado hasta nuestros días. Hoy no podemos recuperar, dice, esos textos de los que no hay ninguna huella fuera de nuestra memoria, pero podemos escribir otros similares («alios illis similes»), lo que no sería inoportuno y quizás viniese requerido por la fuerza del destino ${ }^{16}$.

La desaparición de libros se produce, según el anónimo, por la incuria o la maldad de los hombres o porque devienen superfluos o dejan de ser del agrado del público o porque un incendio u otra catástrofe los reduce a la nada. Lo cierto es que fueron pasto de las llamas los setecientos mil volúmenes de la Biblioteca de Alejandría y desaparecieron algunos libros de Cicerón y la mayor parte de las historias de Livio y Salustio, así como un montón ("congeries») de obras de Varrón, aunque una parte de los que versaban sobre la religión de los antiguos fue destruida por el papa Gregorio VII, que redujo a cenizas muchísimos otros escritos de la lengua latina por considerarlos ofensivos para un cristiano, igual que hizo Gregorio Nacianzeno con los libros griegos ${ }^{17}$.

En el prólogo dice que, como otro Teofrasto redivivo, se propuso escribir esta historia (de los dioses), aunque con un espíritu diferente: «aquel, en cuanto pagano, y, si no me equivoco, riéndose de los dioses; yo en cambio, en tanto que cristiano, venerándolos con toda religiosidad y buscando y reclamando en su defensa armas contra los argumentos de los filósofos, sin que mi fe se vea mancillada ni un ápice por tantas herejías como contiene el libro» ${ }^{18}$.

Igual que Plutarco escribió el Contra Colotes, donde expone la doctrina de Epicuro sobre la mortalidad del alma y la negación de la providencia de los dioses, casi un compendio e imagen de cosas monstruosas, con la intención de demolerlo y refutarlo, el anónimo dice haber compuesto y escrito su libro para los doctísimos teólogos, para confundir a los ateos y destruirlos con sus mismos argumentos y con razonamientos válidos. De ese modo, dice, frente a los acuciantes argumentos de tantos filósofos, cuya solución ignoramos, «sólo hay para mí una solución: es contrario a la fe, luego lo que dicen es falso» ${ }^{19}$.

De los seis tratados de que se compone el Theophrastus redivivus al tema de la eternidad del mundo está dedicado el segundo (De mundo), dividido en siete

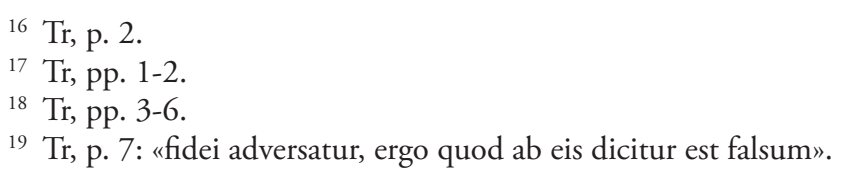


capítulos: 1) in quo ad tractatum de mundi aeternitate fit ingressus, 2) de mundi ortu opiniones, 3) contra mundi creationem, 4) mundi aeternitas, 5) naturae vicissitudines, 6) de tribus temporibus, 7) de aeternitate mundi authoritates. Una vez que, en el tratado primero, concluye que todas las opiniones acerca de los dioses son falsas y que ninguna de ellas puede ser verdadera, a no ser aquella que afirma que no existen ${ }^{20}$, declara que los que consideran que los dioses son la causa del mundo y que este ha tenido un origen, o bien expresan las estúpidas creencias de gentes de buena fe pero iletradas (credulorum imperitorum) o no hacen sino mostrar los delirios (deliramenta) de filósofos y teólogos, o las ficciones (figmenta) de los príncipes y legisladores, para quienes la religión es mera ars politica. Para el anónimo, la religión no entraña ni requiere el conocimiento de Dios, sino que busca el modo de crear y mantener el orden social o civil. Sin ella no habría posibilidad, según la mayoría de los filósofos, de mantener a los hombres sujetos a una vida en sociedad, aunque el anónimo cree que se debería retornar al estado presocial, es decir, al estado de naturaleza, en comunidad con los animales, sin leyes y sin religión, pero siendo todos iguales, sin privilegios ni propiedades. La religión está en el fundamento de las leyes civiles y la formación de los Estados, pero los dioses urdidos por la astucia de los gobernantes son un invento humano, como ya había sostenido el sofista Critias: «un hombre sabio y astuto inventó los dioses».

Los legisladores controlan también, además del poder civil y militar, el poder religioso y tienen a su servicio a los sacerdotes y a los filósofos que no buscan la verdad o no se quieren enfrentar al poder. Por eso, según el anónimo, son muchos los que saben que los dioses no existen y que las almas son mortales, pero aparentan estar convencidos de lo contrario e incluso lo dicen por escrito. Para él, en cambio, la verdadera filosofía no puede admitir la existencia de los dioses ni la inmortalidad del alma, ni los milagros, etc. En su opinión, no puede haber duda del ateísmo de todos los filósofos de la Antigüedad, incluidos Platón y Aristóteles.

Platón, presentado por las escuelas como referente del antiateísmo, fue, según el anónimo, el más ateo de los ateos («contra ateos inducitur qui ateus absolutisimus fuit»), ya que los máximos ateos son los que cuentan de los dioses cosas increíbles, como dice Epicuro. Jamás quiso explicar Platón su auténtica opinión sobre los dioses y, según Diógenes Laercio (Vidas, II, 5), igual que Sócrates fue

$20 \mathrm{Tr}$, p. 171: «fatendum profecto est opiniones, quae de diis feruntur, prorsus esse falsas, nullamque earum veram esse posse, nisi quae illos nullos esse afirmat». 
acusado de ateísmo por Meleto, él tuvo que refugiarse junto a Euclides de Megara para huir de los tiranos de Atenas. Según Trapezuntius ${ }^{21}$, de él derivan todas las herejías y crímenes («a quo haereses omnes et scelera vel orta sunt vel aucta firmataque»), pues fue el predicador de todos los vicios, llegando más allá que sus discípulos: Epicuro y Mahoma.

En cuanto al ateísmo de Aristóteles: «Lo que Aristóteles, puntal de la escuela, piensa sobre los dioses se evidencia a partir de su defensa de la eternidad del mundo. Aunque los teólogos creen que su opinión sobre los dioses es sincera, lo que se deduce de sus escritos muestra con toda seguridad que fue ateo y que solo habla de los dioses por temor al pueblo, pero, al final fue expulsado de Atenas por impiedad $»^{22}$. Pero no solo fue ateo, sino que negó la inmortalidad del alma, por lo que difícilmente su pensamiento es conciliable con lo que sostiene la Iglesia. Su filosofía, sin embargo, fue considerada a partir del siglo XIII como la verdadera filosofía, a pesar de sostener que el mundo es eterno y negar, según la vía interpretativa seguida por Pomponazzi, la inmortalidad del alma, base de todo el edificio de las creencias del cristianismo.

No en vano, bajo el papado de León X, en la octava sesión del Concilio Lateranense (1512-1517), se decretó que los que defendían la mortalidad del alma, la unicidad del intelecto agente y la eternidad del mundo, se desviaban de la doctrina de la Iglesia, es decir, de la recta fide. Como no puede haber — prosigue diciendo el anónimo autor del Theophrastus redivivus - un doble rasero de la verdad, todo aquello que es contrario a lo que la religión enseña, está de acuerdo con la manifesta ratio y, en consecuencia, se ha de concluir que el mundo es eterno y que los dioses no existen ${ }^{23}$. El decreto conciliar ordenaba a los profesores de filosofía que «evitasen cualquier argumentación en público sobre la eternidad del mundo («Iubentur publice docentes philosophi cuncta de mundi aeternitate argumenta excludere»), puesto que si se suprime esta idea de Moisés sobre el nacimiento del mundo, parece que se viene abajo la base de la religión cristiana y toda ella se disuelve en la nada («quia ista de ortu mundi opinione a Mose tradita sublata, christianae religionis fundamentum annihilari videtur»). Evidentemente, el principal pilar de la religión cristiana es la opinión de la creación del mundo. De modo que si el mundo es eterno, Dios no existe.

21 Georgios Trapezuntius, Comparationes philosophorum Aristotelis et Platonis (Venecia, 1523), cit. en Gregory (1979), p. 22.

22 Tr, p. 34.

${ }^{23} \mathrm{Tr}, \mathrm{p} .172$. 
El anónimo rechaza de plano el concepto de creación, pues «crear es hacer algo ex nibilo, cosa inconcebible con la mente y que no se puede expresar con palabras, puesto que es un no-ente. Por tanto, parece imposible afirmar que algo se base en la nada ${ }^{24}$. Moisés condenó — dice siguiendo a Bodino- a pena capital a quienes quebrantasen el sábado, porque ello suponía la puesta en duda de la creación ${ }^{25}$. La opinión de que el mundo tuvo un origen, tan fanáticamente arraigada en el ánimo de los cristianos y otros seguidores de la ley mosaica, se basa, según el anónimo, solo en la autoridad de la religión: «Todos esos desprecian a los filósofos y siguen a los teólogos. Por el contrario, quienes tienen una mente empapada de los razonamientos de los filósofos y se permiten argumentar libremente y sin ataduras, no temen afirmar la eternidad del mundo, como quiera que es acorde con la razón y la naturaleza, cuya autoridad es tanto más fuerte y poderosa cuanto más débil es ese invento de la fe religiosa responsable de la idea de la creación del mundo. Una vez destruida esa invención, no hay duda de que se eliminará el error ${ }^{26}$. Si el mundo es eterno, Dios no existe ${ }^{27}$.

El anónimo rechaza de plano la interpretación racional del mito y niega que sean verdaderas las fábulas que se narran sobre los dioses en las diferentes religiones (cristiana, judía, mahometana y pagana) ya que cada una los representa de una manera. Todas se dicen reveladas y lo que una defiende es tenido como monstruoso, portentoso y falso por las otras ${ }^{28}$. Todas coinciden, sin embargo, en que el hombre ha sido creado por Dios. Adán sería el primer hombre y después de él vendrían todos los demás.

El anónimo, de acuerdo con Aristóteles, sostiene que el hombre es eterno en cuanto especie, no individualmente, igual que las plantas y los animales ${ }^{29}$. Es ridículo buscar el origen de estas cosas que desde la eternidad en un mundo eterno se suceden siempre ${ }^{30}$. Lo que implica que no es posible la evolución ni

24 Tr, p. 206.

25 Tr. p. 336: «Idhirco Moses, ut scribit Bodinus, capitali poenae subiecit eos qui sabatum violarent, ea potissimum de causa quod mundi creationem sabathi violatione in dubium revocare viderentur».

26 Ibidem.

27 Tr, p. 182: «mundum autem aeternum est ostendendum vicissim est, ideo nihil esse deum».

28 Tr, p. 928.

${ }_{29} \mathrm{Tr}$, p. 176: «ex iis enim quae generantur, corrumpantur etiam necesse est, plantas v. g. et animalia corruptibilia videmus, quia generabilia, sed tamen illorum species ab aeterno fluisse certum est».

${ }^{30}$ Ibidem. 
la aparición de nuevas especies. El hombre «es generado por el hombre y por el sol $\aleph^{31}$, pero no surge como los animales inferiores del limo de la tierra por generación espontánea, como sostuvieron Diodoro Sículo, Avicena y Cardano, o por evolución, como defiende Vanini, que cree que procede del mono (aunque esto no lo dice el anónimo).

Hay muchas similitudes entre el relato del Génesis y lo que podemos leer en algunas fuentes griegas y latinas, como Píndaro (Olimpicas, IX) y Ovidio (Metamorfosis, I, 350-394). En el Génesis se dice que el señor Dios formó al hombre del lodo de la tierra inspirándole en el rostro un soplo o espíritu de vida, y que así quedó hecho el hombre viviente con un alma racional. En Génesis 6 y 7 , se hace referencia al diluvio, al arca y al pacto con Noé. En Píndaro y Ovidio encontramos el relato de un diluvio universal provocado por Zeus así como el del arca varada en el monte Parnaso en la que únicamente se salvaron, de entre miles de seres humanos, Deucalión, hijo de Prometeo, y su esposa Pirra, hija de Epimeteo. Asimismo, se dice que la nueva generación de varones y hembras ha surgido a partir de las piedras lanzadas por ambos. Ovidio cuenta cómo los pedruscos lanzados por la mano de Deucalión cobraron el aspecto de hombres, mientras que los lanzados por Pirra se tornaron en féminas. A los demás animales los habría producido la tierra por sí misma, después de que el cieno y las húmedas charcas se hincharan por el calor.

El anónimo niega que pueda haber mundos infinitos o finitos como sostenían los maniqueos y los seguidores del Talmud. Por mundo se ha de entender el mundo sensible y único. No es admisible una innumerable infinitud de mundos que nacen como las setas ${ }^{32}$ y se destruyen cada día, como decía Demócrito. Urdir tales mundos es un sueño y una temeridad, que no se corresponden con lo observado en la experiencia. Rechazadas estas ficciones, se ha de decir, siguiendo el De mundo, atribuido a Aristóteles, que «el mundo es una estructura (compages) trabada de cielo, tierra y las naturalezas que se contienen en ellos» ${ }^{33}$.

Partiendo del rechazo de la infinitud y pluralidad de mundos, el anónimo aborda las dificultades de la tesis creacionista: si Dios creó todo lo que hay en el universo, tuvo que estar en algún lugar, pero si así fuera, sería un cuerpo, pues no cabe imaginar un cuerpo infinito. Luego, antes de la creación, hubo un lugar

31 Aristóteles, Física, II, 194 b 13.

32 Tr, p. 182: «veluti fungos nascentium».

33 Ibidem. 
y un cuerpo, de donde se sigue que hubo algo antes de que hubiera algo. Por tanto, es claro que la nada no puede ser de ninguna manera ni es posible que se haya creado cosa alguna a partir de ella ${ }^{34}$. Nada es más absurdo que afirmar, como Moisés, que Dios creó una tierra estéril y vacía y que las tinieblas se cernían sobre la faz del abismo, y que Dios desde toda la eternidad yacía sobre ellas cuando el mundo aún no había sido creado. Además, si Dios está en todas partes no estará más en un lugar que en otro, luego es ridículo afirmar que «el espíritu de Dios se movía sobre las aguas». Cuando se afirma que Dios dijo «hágase la luz, y vio que la luz era buena», uno — dice el anónimo — no puede dejar de asombrarse, "pues queda claro con ello que es un hombre el que está escribiendo y que ha hablado de modo completamente humano». ${ }^{35}$ Es ridículo pensar que Dios necesita de luz, pero no es menos digno de risa decir que creó la luz antes de crear el Sol, la Luna y las estrellas, únicas fuentes de la luz. ${ }^{36}$ Pero, además, ¿¿dónde está esa luz primigenia? En ningún lugar, luego no existe.

Por otra parte, hasta el cuarto día no creó el Sol. Luego el Sol y la Luna no pueden ser esa luz primigenia, que no es más que una ficción. No menos ridícula es la afirmación de que la tierra, por orden de Dios, produjo hierba y frutos antes de que fueran creados el Sol y los astros. ¿Qué decir de que Dios creó al hombre a su imagen y semejanza? En ese caso, Dios no se diferenciaría del hombre y tendría, como él, cuerpo y alma y, en consecuencia, estaría expuesto, como el hombre, a la muerte. Luego es falso que el hombre haya sido creado a imagen y semejanza de Dios y que tenga dominio sobre los demás animales. Al contrario, habría que decir que «a las bestias se les ha dado poder y mando sobre los hombres ${ }^{37}$. Moisés se contradice en lo de la creación del hombre, pues, en Génesis 1, dice que Dios «los creó macho y hembra», mientras que en Génesis 2 sostiene que formó al hombre de barro de la tierra y a la mujer de una costilla de Adán. Cuesta entender cómo, según el Génesis, Adán es creado por Dios, soplando sobre el barro, mientras que todos los demás hombres proceden de una generación seminal y necesitan un padre y una madre. ¿Qué edad tenía Adán cuando fue creado?

El anónimo tiene una concepción gnoseológica empirista en la que los conceptos se forman a partir de la percepción de los sentidos; de modo que aquello

\footnotetext{
34 Tr, p. 206.

35 Tr, p. 214: «In hoc quidem manifestum est et hominem esse qui loquitur, et more humano prorsus locutum esse».

$36 \mathrm{Tr}$, p. 216.

37 Ibidem.
} 
de lo que no tenemos percepción sensorial es para él una ficción. De Dios no tenemos ninguna percepción sensorial, luego, según el anónimo, no existen ( $A t$ de deo per sensus nulla esse potest notio: igitur figmentum esse inferre neccese est»). Por eso dice que para los filósofos antiguos los dioses son los astros, porque son visibles desde cualquier lugar por todos. Es curioso que el anónimo no tenga en cuenta que Epicuro negaba las divinidades astrales porque para él todo se compone de átomos, tanto lo celeste como lo terrestre. Gassendi, que profesa también un empirismo y niega, frente a Descartes, el innatismo de las ideas, admite, sin embargo, que del hecho de que no tengamos experiencia sensorial de Dios o del alma no se deduce que no existan.

Según Epicuro, no vemos los átomos ni el vacío, pero inferimos su existencia por la razón a partir de la analogía con ciertas observaciones de la experiencia: la reja del arado desgastada por el uso, o las escalinatas del templo de tanto ser pisadas, o las estatuas de los dioses a causa de los besos de los hombres; lo que nos lleva a pensar que los cuerpos se componen de elementos más pequeños que no vemos. En suma, el concepto de percepción sensorial no es un criterio decisivo para deslindar lo real de lo imaginario, como supone el anónimo. Hay animales tan pequeños que no los vemos a simple vista y cuerpos tan alejados que solo son visibles con el uso del telescopio. Galileo cambió el paradigma de la ciencia, aunque el anónimo no lo menciona nunca, como tampoco a Gassendi, conocedor a fondo de la filosofía epicúrea.

Por otra parte, siendo cierto, como dice Gassendi, que hay pueblos que no tienen ninguna noción de Dios, no se puede decir que nacemos con esa idea, pero tampoco negar su existencia. Epicuro decía que los dioses no se conocen con los sentidos sino con la mente, aunque hay una discusión enconada entre los partidarios del innatismo de las prolepseis de los dioses (Cicerón) y los que sostienen que se derivan de la experiencia (Gassendi). Según el anónimo, examinando el nombre de Dios conoceremos cuál es su verdadera significación y si es un verdadero ente o una ficción. De ahí la creencia de que el nombre de Dios, desde los egipcios, se aplicaba a los astros.

Del mismo modo que un pintor, dice el anónimo siguiendo a Lucrecio, no puede pintar un caballo si éste no existe, Dios tampoco pudo crear la luz ni ninguna otra cosa de las que están en el mundo si no tuvo una idea anticipada de ellas, pues las ideas no son más que imágenes de las cosas que para ser pensadas deben ser antes percibidas sensorialmente. ¿De dónde le llegaron a Dios si las cosas aún no habían sido creadas? No vale decir que esas cosas superan el enten- 
dimiento humano. Moisés desvariaba al escribir cosas tan imposibles («Moses igitur deliravisse dicetur») $)^{38}$.

Platón, del que decía Numenio que era «un Moisés que hablaba griego ático", nos ha transmitido la fábula de la construcción del mundo a partir de los elementos materiales: lo más parecido, según el anónimo, a la creación ex nihilo. Dice que el mundo ha sido hecho, "pues puede verse y tocarse y tiene cuerpo", pero «no se aparta mucho de las historietas de la creación. Y la materia que Platón aduce de esta construcción no es más probable o verosímil que la nada imaginada por Moisés» ${ }^{39}$. O los elementos están constituidos de alguna materia o son eternos, pero si son eternos, el mundo, que no es otra cosa que la trabazón (congeries) de los elementos, también debe serlo. Luego «los elementos no ocuparon ningún lugar antes de la creación del mundo, cosa que parece de lo más absurdo, pero es verdadera " ${ }^{40}$. Según el anónimo, "parece más natural y razonable decir que el mundo es eterno que aseverar que está hecho de una materia eterna, dado que de esta última opinión se siguen cosas mucho más absurdas que de la primera. En una y otra, es verdad, la eternidad produce cierto estupor en la mente humana [...], pero de lo antedicho se deduce que es menos absurdo creer que el mundo es eterno que admitir que ha sido creado y construido a partir de alguna materia ${ }^{41}$.

La mayor de las fábulas es la de la construcción del mundo mediante la creación o a partir de principios ${ }^{42}$. Si el mundo hubiese sido creado o fundado por algún dios, este lo habría creado o por sí o por los seres animados o por alguna de las cosas que en él hay. Evidentemente no lo creó en su beneficio ya que no necesita de ningún mundo; si lo necesitara, no será feliz ni dichoso y por lo tanto tampoco dios; no lo hizo por ninguno de los seres animados ni por otros, ya que aún no habían si creados y no existieron hasta que el mundo fue creado. Luego no fue creado ni surgió a partir de los elementos.

Si Dios no creó el mundo ni por sí ni por otro, se sigue que no fue creado con un plan (consilio), luego lo fue por el azar (casu) o por la suerte (fortuna), lo que es aún más ridículo. Si fuera cierto que Dios ha creado el mundo, aunque lo hubiese hecho hace miles de años, habría un tiempo en el que el mundo aún no estaba creado. Aunque los teólogos dicen que la eternidad carece de sucesión, y

\footnotetext{
38 Tr. p. 221.

$39 \mathrm{Tr}$, p. 224.

40 Tr, pp. 225 ss.

41 Tr, p. 227.

${ }^{42} \mathrm{Tr}$, p. 229.
} 
que en ella no hay un antes y un después, es decir, que no está sujeta al tiempo, se trata de palabras vacías, pues la eternidad medida por el tiempo puede ser mucho mejor entendida que sin tiempo: «Afirmo que es eterno aquello que carece de principio y fin, pero esta definición conviene también al tiempo, que nunca empezó o va a cesar, porque como todo momento es comienzo del futuro y final del pasado, presupone siempre algún tiempo precedente y algún tiempo subsecuente y, como vemos que eso sigue así innumerablemente, hay que pensar necesariamente que nunca empezó ni cesará y que por tanto es eterno» ${ }^{43}$.

Considera qué es la eternidad y esos miles de años incontables que no son nada comparados con ella; aunque digan que Dios es eterno, aunque hubiese creado el mundo desde hace esos miles de años incontables, restaría con todo un tiempo en el que el mundo no había sido aún creado ${ }^{44}$. Luego la eternidad no es más que un tiempo infinito ${ }^{45}$ y es pertinente plantearse por qué en todo ese tiempo anterior a la creación o estructuración del mundo por Dios, no fue creado o estructurado. No se comprende la creación, constitución o generación del mundo sin comprender qué es el espacio, el tiempo y el movimiento. Antes de la constitución del mundo no había lugar y por tanto tampoco nacimiento. Y no vale decir que el mundo deriva del caos, porque podríamos entonces preguntarnos de dónde deriva éste, que no es más que una cosa imaginaria. Tampoco es posible afirmar que antes del tiempo existió el mundo, pues una cosa existiría antes de ser engendrada, lo que es absurdo. Luego todo lo que nace es preciso que nazca en el tiempo. Pero si el tiempo no tiene nacimiento (ortum), antes de la construcción del mundo, no pudo ser constituido, sino en el tiempo. Por tanto se ha de concluir que no fue constituido ni tuvo origen; luego es eterno ${ }^{46}$.

Como, según Aristóteles, el tiempo es perpetuo, también lo será el movimiento, ya que el tiempo no se da sin el movimiento, sino que es número y afección (affectio). Pero si el movimiento es eterno, también el cielo es eterno, pues, según Aristóteles, está en movimiento perpetuo. El primer móvil se mueve por tiempo infinito con movimiento eterno y el mundo, por esta razón, es eterno. ${ }^{47}$ Queda patente y más claro que la luz que «el mundo es eterno, que siempre ocupó el sitio que ahora ocupa y que el tiempo que vemos durar y el

\footnotetext{
43 Tr, p. 230.

${ }^{4} \mathrm{~T}$ Tr, p. 229.

45 Tr, p. 230: «Igitur et aeternitatem non esse nisi tempus infinitum».

$46 \mathrm{Tr}$, p. 236.

47 Aristóteles, Física, VIII, cap. 10.
} 
movimiento que hace generar al universo son cosas eternas, y que, por tanto, el mundo ni ha sido hecho ni ha nacido" (ideoque nec factum esse nec ortum esse mundum). ${ }^{48}$

El anónimo, que se declara seguidor de Aristóteles ${ }^{49}$, rechaza que el mundo haya surgido en el tiempo y que haya sido hecho a causa de las criaturas, como han expresado claramente Cicerón y Lucrecio ${ }^{50}$. Cicerón ${ }^{51}$ pone en boca del epicúreo Veleyo las objeciones a la teoría platónica del Timeo, a la que califica de invención sin fundamento, y a la Providencia de los estoicos. Lo que le resulta a Veleyo más chocante es la pretensión de Platón de que el mundo, que ha tenido un comienzo, perdure eternamente en el tiempo. ¿Cómo pudo el arquitecto hacer que le obedezcan el aire, el fuego, el agua, la tierra? ¿De dónde nacieron aquellas cinco formas o figuras, a partir de las cuales se forman todas las demás? En cuanto a Epicuro, ciertamente, niega que el mundo haya sido creado por los dioses en beneficio de lo hombres, con lo que queda claro, según el anónimo, que «no hay que tener al hombre en tan alta estima como para creer que por mor de él se ha levantado la fábrica del mundo o imaginar que los dioses (si es que los hay) hayan puesto manos a semejante construcción». ${ }^{52}$ Examinaremos más adelante con detalle si el pensamiento del anónimo refleja con exactitud la doctrina epicúrea sobre la eternidad del mundo. Llama poderosamente la atención que, en la larga cita que hace del De rerum natura (V, 146-147; 156-87; 195-234), no tenga en cuenta la explícita negación de la eternidad del mundo por parte de Lucrecio. No fue el mundo creado por los dioses, pero tampoco es eterno. Para Lucrecio los dioses son eternos, pero no lo son ni el mundo ni sus partes.

Dentro del contexto creacionista, para el anónimo, aquellos que afirman que el mundo ha comenzado hace seis mil años, están $\operatorname{locos}^{53}$. El número de años que hoy se cuentan entre los cristianos desde la creación del mundo «no hay que tenerlo en consideración, sino más bien rechazarlo como falso y absurdo, ya que

${ }^{48} \mathrm{Tr}, \mathrm{p} .237$.

$49 \mathrm{Tr}$, p. 240: «quapropter hanc Aristotelis doctrinam sequentes».

50 Tr, p. 231: «His Ciceronis, contra mundi aedificium, rationibus ea quae pari mente Lucretius versibus fudit, ut ex utroque scibendi genere, oratorio et poëtico, veritas eliciatur, firmiusque persuadetur, neque a diis universum esse conditum, neque hominum causa (qui soli talia credunt), quidquam esse factum».

51 Cicerón, De natura deorum, I, viii, 19; IX, 23.

$52 \mathrm{Tr}$, p. 234.

53 Tr, p. 327: «Et certissime saltem probant delirare eos qui rerum exordium a sex milibus annis deputant». 
hallamos miles de años más allá de ese límite en los documentos de los antiguos y la astronomía nos enseña que el tiempo es infinito y que las revoluciones de los astros también lo son ${ }^{54}$. Pero que "el mundo fue creado hace seis mil años, sólo se cree por la religión cristiana, pero esa idea es falsa; y la opuesta, que asegura que es eterno, es verdadera ${ }^{55}$. Los judíos son posteriores a los egipcios y a otros pueblos. Su antigüedad se remonta, según el anónimo, al 3983 antes de Cristo, con lo que, si le añadimos 1659, resultan 5642 años $^{56}$. Según Diodoro Sículo los documentos caldeos se remontan a 470.000 años y los egipcios a 50.000. Las tablillas de los babilonios, según Plinio, tienen 730.000 5 .

El mundo está sujeto a constantes cambios, mínimos y máximos. Los primeros se producen cada día, como las generaciones y corrupciones ordinarias, los máximos ocurren, con intervalos de siglos, desde toda la eternidad, infinitas veces («sed tamen ab aeterno infinities»), de acuerdo con la ordenación de la naturaleza («ex ordine naturae») $)^{58}$. Estos movimientos se generan mediante cataclismos y derrumbes («iluviones») o mediante conflagraciones y diluvios. Pero estos diluvios y conflagraciones no son universales, sino que afectan a unas tierras y a otras no, lo que explica que algunos hombres y animales se salvaran para perpetuar sus especies. De esta opinión fue Aristóteles, según Celio Rhodigino: «Se cree que Aristóteles, en el libro sobre las propiedades de los elementos, transmitió a la posteridad que cuando todos los planetas se reúnan en el signo de Piscis, todo se convertirá en agua; y cuando la conjunción ocurra en Géminis se producirá la conflagración del universo»" ${ }^{59}$. Según Hermes Trismegisto, Dios, para eliminar la vejez del mundo y borrar las culpas de los hombres, provoca unas veces cataclismos, otras conflagraciones, otras epidemias. Para Heródoto, Solino y Pomponio Mela, los egipcios conservan la tradición escrita de su historia en un tiempo en el que los astros han cambiado cuatro veces su curso y el Sol por dos veces se ha puesto por donde hoy sale. De donde resulta, según Olivarius, que la antigüedad de los egipcios se remonta a 144.000 años. Según Escalígero, los mejicanos, cuyos cómputos comienzan en 694 antes de Cristo, dicen, como lo egipcios, que hasta

\footnotetext{
54 Tr, p. 326.

55 Tr, p. 327.

56 Tr, p. 317.

$57 \mathrm{Tr}$, p. 324.

$58 \mathrm{Tr}$, p. 266.

59 Tr, p. 268 ss.
} 
el día de hoy (1659) se destruyeron cuatro soles. También Platón dice que el movimiento del universo puede ir en un sentido o en su contrario ${ }^{60}$.

\section{Epicureísmo, estoicismo, y escepticismo en el Theophrastus redivivus}

Entre los autores preferidos por el anónimo están todos aquellos que, a su juicio, defienden algo contrario a la creencia religiosa en general, aunque sobre todo contra la cristiana. Por eso, entre los antiguos, prefiere a Lucrecio, Sexto Empírico y Luciano. Lucrecio, siguiendo a Epicuro del que se declara mero expositor, aunque no niega la existencia de los dioses eternos y antropomorfos, los considera ociosos, sin intervención en la naturaleza, alejados del mundo y sordos a las súplicas de los hombres. En el plano físico o natural, todo se explica en el atomismo por la unión y desunión de átomos eternos e infinitos que, moviéndose en un vacío también infinito, dan lugar a infinitos mundos que se hacen y se deshacen, que nacen y mueren. Y eso no se concilia con lo que el anónimo sostiene, como ya hemos dicho. Resulta curioso, sin embargo, que se salte justo los versos en los que Lucrecio se declara partidario de la pluralidad de mundos que nacen y desaparecen.

En cuanto a la corriente escéptica, el anónimo cita profusamente a Sexto Empírico, autor que, si bien no se pronuncia con rotundidad, es decir, dogmáticamente, sobre nada, puede ser considerado un freno frente al dogmatismo religioso. De él y de Bodin pudo deducir el anónimo su tesis de que todas las religiones tienen igual fuerza y cada una prueba su verdad a partir de la falsedad de las demás, por lo que todas las creencias tienen igual valor. En ese sentido, el anónimo declara que todas las religiones son buenas, es decir, útiles. Ni siquiera se puede afirmar que será más verdadera la religión que tenga mayor número de seguidores, puesto que la verdad no es una cuestión de cantidad, aunque, siguiendo a Pomponazzi, declara que la religión mahometana o sarracena, si el criterio fuese cuantitativo, sería superior a las demás porque tiene muchos más seguidores que la judía y la cristiana juntas. Acerca de la diferencia entre las tres religiones, el anónimo cita a Boccaccio (los tres anillos) y a Bodin, que en el Coloquium heptaplomeres de rerum sublimium arcanis abditis, pone en boca de uno de sus personajes su preocupación por acertar en materia de religión y, a tal

60 Platón, Politico, 268 a. 
fin, dice que asiste a los cultos de todas las sectas para asegurarse de topar con la verdadera.

¿Qué decir, en fin, de Luciano, que se burla de todas las sectas por igual, pero pone el dedo en la llaga de la credulidad humana, principalmente en materia de religión, como comprobará el lector de Alejandro o el falso profeta, obra en la que se cuenta el nacimiento de una impostura religiosa? La impostura es un tema central en el anónimo, que declara, siguiendo una larga tradición, que Moisés, Cristo y Mahoma son los grandes impostores de la historia de la humanidad y que la religión no es otra cosa que una invención de los poderosos, esto es, de los príncipes y de la jerarquía religiosa.

En el capítulo VII del segundo tratado, sostiene el anónimo que la eternidad del mundo era defendida abiertamente por los filósofos en la Antigüedad, «mientras que ahora lo hacen clandestinamente por miedo a la religión» ${ }^{61}$. A continuación, inicia un barrido histórico y expone la opinión de todas las autoridades contrarias a la creación («ese invento de Moisés»): Tales, Anaximandro, Heráclito, Ocelo de Lucania, Filolao, Aristeo, Alcmeón de Crotona, Ferécides de Siro, Empédocles, Aristóteles, Teofrasto, Critolao, Filón, Proclo, Plinio, Averroes, Bodin, Pomponazzi, Cardano, Vanini, etc., han defendido — dice— la eternidad del mundo frente a la doctrina creacionista de Moisés.

El anónimo es un ecléctico, pero se siente cómodo con todos los autores que, según él, han negado la existencia de los dioses o su providencia, y, a este respecto, Epicuro es el paradigma a seguir, ya que solo habla — dice el anónimo siguiendo a Cicerón (De natura deorum) — de los dioses por temor al pueblo, pero en realidad es el destructor de toda religión, pues ¿̨qué pueblo aceptará unos dioses que no le favorecen ni le responden aunque les rinda sacrificios? Pero, a diferencia de lo que sostiene el anónimo, los partidarios de que el mundo tuvo un origen no siempre se basan en las creencias religiosas. Epicuro sostiene que los dioses son eternos, junto con los átomos y el vacío, aunque no el mundo o, mejor sería decir, los infinitos mundos. El término latino mundus equivale al kósmos de los griegos, que significa ordenación o disposición de los elementos de una serie. Esa ordenación, en el atomismo, no es obra de una divinidad, sino producto del choque impredecible (y por tanto indeterminado y azaroso) de infinitos átomos moviéndose en el vacío infinito. El encuentro de los átomos que habrán de formar los mundos se explica, según Lucrecio, mediante el clinamen o desvia-

${ }^{61}$ Tr, p. 328: «Antiquitus palam tuebantur eam, nunc clam ob religionis metum». 
ción atómica que se produce loco incerto, tempore incerto, y que, supuestamente, Epicuro habría denominado parénklisis. Con independencia de la dificultad que plantea la hipótesis del principio de desviación atómica — dificultad señalada claramente por Cicerón que veía en ella algo risible - siempre existieron aglomeraciones de átomos, producidas en función de las diferencias formales de los prima corpora, u ordenaciones de cuerpos que aparecen y desaparecen infinitas veces. Es la naturaleza misma, no los dioses, la que produce cuanto existe. Pero los dioses no son meras invenciones humanas para Epicuro, como sostiene el anónimo siguiendo a Cicerón. En efecto, en la Carta a Meneceo, 124, afirma categóricamente que tenemos de ellos un conocimiento proléptico, esto es, cierto y evidente, no una falsa suposición (pseudes hypolepsis). Su eternidad se debe a que no están en un mundo u ordenación, sino en los intermundia, donde ninguna fuerza les afecta. En realidad, el epicureísmo no es, a diferencia de lo que afirman el anónimo y tantos otros de sus expositores, una filosofía que propugne el ateísmo, a no ser que por ateísmo se entienda la negación de la providencia divina y/o de la inmortalidad del alma. Como es sabido, Gassendi, el gran estudioso del atomismo, intenta una conciliación de Epicuro y el cristianismo (algo que, según dirá Marx, es como vestir a la Lays griega con el manto de una monja cristiana). No cree Gassendi que Aristóteles sea más compatible con el cristianismo que Epicuro. Tampoco lo es Platón, que habla de la transmigración de las almas, lo que supone negar de plano la inmortalidad personal.

Esa irrefrenable pasión que siente el anónimo por la filosofía epicúrea, y sobre todo por Lucrecio — que señala los males de la religión («tantum religio potuit suadere malorum» $)^{62}$ pero admite la existencia de dioses de humana figura y eternos que no se cuidan de los hombres ni del mundo- no implica que el autor del Theophrastus redivivus renuncie a la filosofía aristotélica para abrazar el atomismo. Al contrario, permanece, aunque con matices, fiel a su verdadera fuente de inspiración, el peripatético renacentista Pietro Pomponazzi, que, a su vez, también compartía algunos elementos de la filosofía epicúrea. Es sabido que Agostino Nifo, en su Libellus contra el De immortalitate animae de Pomponazzi, lo tacha abiertamente de epicúreo («ut arbitrantur Pomponatius et Lucretius») ${ }^{63}$. Y no solo Nifo, también Cardano lo considera epicúreo. Con todo, hemos de recordar que el anónimo se declara seguidor de Aristóteles, more pomponatiano, y no admite, en consecuencia, ni la existencia del vacío ni la de los átomos, haciendo suya, aunque no de modo explícito, la crítica aristotélica al atomismo

${ }^{62}$ LuCrecio (1976), libro I, 101.

${ }_{63}$ Nifo (2009), cap. 47, p. 192. 
de Demócrito. Por supuesto, tampoco considera el anónimo que mediante el azar se pueda dar razón de la formación de los cuerpos, como pretende Lucrecio con su clinamen. En realidad, en el siglo XVII, la doctrina atomista no contó apenas con partidarios hasta Gassendi, traductor, intérprete y divulgador de la doctrina de Epicuro, aunque no lo cita nuestro autor, como ya hemos dicho, a pesar de aceptar, como él, los principios psicológicos, éticos y sociales del epicureísmo. En Spinoza sucede algo similar, pues niega el vacío y los átomos, pero acepta muchas de las tesis epicúreas: mortalidad del alma, hedonismo, negación de la providencia, del azar, etc.

La filosofía epicúrea está presente en el Theophrastus redivivus, sobre todo, en el tema de la mortalidad del alma y en la doctrina moral del hedonismo; pero en relación con el tema de la eternidad del mundo, Epicuro no es un aliado, sino un serio adversario, aunque el anónimo dice que «al vulgo no le va bien imaginarse unos dioses eternos ociosos en un mundo eterno («ideoque oportuit illi non deos aeternos in aeterno mundo otiosos fingere»), sino que es mejor considerarlos laboriosos, artesanos, obreros, despiertos y previsores de cada cosa, en vez de hacerlos haraganes y ajenos a todo quehacer ${ }^{64}$. Lucrecio, que es la verdadera fuente del anónimo en este pasaje con el que arranca el capítulo I del De Mundo, no puede ser un aliado porque el mundo no es obra de un dios sino de la naturaleza - que no ha sido preparada en nuestro interés por obra divina, tan grandes son sus defectos ${ }^{65}$ - y tampoco es eterno e inmortal ${ }^{66}$. No son eternos ni el mundo, ni sus partes, ni la tierra, ni el mismo cielo ${ }^{67}$. El mundo es el resultado de una acumulación de materia (congressus materiai) de la que surgieron el cielo, la tierra, el mar, los astros, el Sol, la Luna y los seres vivos, incluidos los hombres. Pero consta de un cuerpo mortal («mortali consistere corpore mundum») y tuvo un origen («nativumque simul») y no puede perdurar incólume eternamente («nec posse incolume magnum durare per aeuom») ${ }^{68}$. El mundo tendrá un fin: «en un solo día el mar, la tierra y el cielo desaparecerán y esta mole y fábrica del mundo se derrumbará después de estar en pie durante tantos años» ${ }^{69}$.

${ }^{64} \operatorname{Tr}, 175$.

65 Cf. Lucrecio (1976), V, 199: «nequaquan nobis divinitus esse paratam naturam rerum; tanta stat praedita culpa».

${ }^{66}$ Ibid., V, 159: «aeternumque putare atque immortale futurum, nec fas esse».

${ }^{67}$ Ibid., V, 245.

68 Ibid., V, 61.

69 Ibid., V, 95 ss.: «una dies dabit exitio, multosque per annos sustentata ruet moles et machina mundi». 
En el mecanicismo epicúreo el problema radica, más bien, en explicar cómo el mundo sigue existiendo cuando las fuerzas de dispersión están impulsándolo a disgregarse en el vacío absoluto. Por eso dice Lucrecio que si no hubiera un límite a la división de la materia, el infinito tiempo pasado («longa diei infinita aetas anteacti temporis omnis») lo hubiera destruido ya todo sin posibilidad de repararlo en el tiempo restante: «si la naturaleza no hubiese fijado un límite a la destrucción de las cosas, a tal extremo estarían ya reducidos los elementos materiales, que nada engendrado por ellos, por la acción destructora de los siglos, podría en un tiempo determinado (certo tempore), alcanzar la plenitud de la vida» ${ }^{70}$.

Fue la debilidad de la razón (rationis egestas), la que, como dice Lucrecio (V, 1211), llevó a los hombres a preguntarse si este mundo tuvo nacimiento (mundi genitalis origo) y si ha de tener fin y hasta cuándo resistirán las murallas del mundo este movimiento silencioso, o si ha sido dotado por los dioses de existencia sempiterna. Los hombres, al observar el cielo y el orden que en él hay, no tenían otro recurso - dice Lucrecio - que remitirlo todo a los dioses y hacer que todo girara a una señal (nutu) suya. Ese es el origen de sus males: la falsa piedad de la religión, que atribuye un poder infinito a los dioses, en vez de «considerar todas las cosas con mente serena ${ }^{71}$.

En suma, a pesar de que, según el anónimo, casi todos los filósofos antiguos creyeron que el mundo era eterno («ideoque omnes fere antiqui philosophi aeternum mundum crediderunt»), entre lo que él dice y lo que leemos en Lucrecio acerca de la eternidad del mundo, no hay conciliación posible; como tampoco la hay con los estoicos, que, a causa de la ekpyrosis o conflagratio, sostenían que cada cierto periodo de tiempo todo se convertiría en fuego y desaparecería para volver a retornar. Lo curioso es que Heráclito, el modelo seguido por el estoicismo, defendía la eternidad del mundo, como se ve en el fragmento 30: «este mundo no lo hizo ninguno de los dioses o de los hombres sino que es, ha sido y será fuego eternamente viviente que se enciende y se apaga según medidas». Para los estoicos, en cambio, a diferencia de la pluralidad sostenida por Anaximandro y los atomistas, el mundo es uno, pero es producido en el tiempo y corruptible. Lo único eterno será la palingenesia cíclica.

70 Ibid., I, 551 ss.

${ }^{71}$ Ibid., V, 1203: «pacata mente omnia tueri». 
Según Estobeo, hay dos clases de fuego: uno artífice (technikon), que crea el mundo («ignem [...] artificiosum ad gignendum progredientem via»), como dice Cicerón $\mathrm{n}^{72}$, y contiene las razones espermáticas de todas las cosas (plantas, animales, hombres, alma del mundo); y otro atechnon que consume y asimila todo lo demás. En cualquier caso, mientras que el fuego atechnos se identificaba con Hefesto e igual que él era cojo, es decir, necesitaba la materia combustible a modo de bastón en el que apoyarse, el fuego artífice es el verdadero creador de todo y se identifica con Zeus, inmanente al mundo. En eso se distancia el materialismo estoico del epicúreo, que situaba a los dioses en los intermundia, es decir, fuera del mundo. Ese panteísmo estoico, que identifica el fuego con Zeus y declara que Dios es todo lo que ves y lo que no ves (como dice Séneca), plantea un gran problema: el de la regeneración del universo después de la ekpyrosis o conflagración universal, pues implica, como dice Filón (De aeternitate mundi, 76), primeramente, que el mundo es engendrado y corruptible (genetos kai phthartos ho kosmos), pero, en segundo lugar, que surge del no ser. Ahora bien, siendo eso imposible, ya que no hay en el mundo una causa interna o externa de su destrucción, es necesario admitir la doctrina de su inengendrabilidad e indestructibilidad de acuerdo con Aristóteles. Con razón Filón tituló su diálogo Peri aphtharsias tou kosmou.

Panecio de Rodas y Diógenes de Babilonia abandonaron el estoicismo de Crisipo por el aristotelismo o al menos suspendieron el juicio sobre la conflagración del universo, según Ario Dídimo, justamente porque, si todo se conflagrase, ¿cómo se explicaría la nueva diakosmesis o renovación del mundo? Si no queda ninguna razón seminal en las cenizas (medenos entipsomenou spermatikou logou) y el fuego mismo se acaba al agotarse el combustible, es evidente que el mundo no tiene nacimiento ni corrupción, es decir, es agénetos kai áphthartos, como sostiene Filón en De aeternitate mundi, 93.

\section{El encuentro con Filón de Alejandría y el neoplatonismo}

Aunque lo que en realidad se propone el anónimo es demostrar la falsedad de la religión cristiana, su análisis del hecho religioso en general va más allá y le lleva a hablar de la pagana, la judía y la mahometana. Sin embargo no incluye, a diferencia de algunos de sus coetáneos, el pensamiento oriental: chino, indio, japonés, etc. En cambio, a través de la obra de Francisco López de Gómara,

72 Cicerón, De natura deorum, II, 22, 57. 
nunca mencionado por el anónimo, que usa la traducción al francés de Martin Fumée $^{73}$, hace algunas referencias a las creencias recién descubiertas en el Nuevo Mundo. Se interesa, sobre todo, por la religión de los peruanos y de los mexicanos.

Por otra parte, sostiene que lo común a todas las religiones es la suposición de que hay un primer principio del que han surgido el cielo y la tierra, que han tenido un origen y tendrán en algún momento un fin y término, como se desprende de la observación de que en la tierra todo nace y perece ${ }^{74}$. Ese principio —dicen- proviene de un creador eterno que es Dios ${ }^{75}$. Pero, una vez conocida y analizada la naturaleza divina, se ha de concluir que no existe ningún principio, sino que todo está en eterno movimiento de acuerdo con la inmutable ley de la naturaleza, que, según la «razón manifiesta», enseña que el mundo es eterno ${ }^{76}$.

Como quiera que la eternidad ha de corresponder al artífice (Dios) o al mundo, es más probable y más verosímil creer que se dé en el mundo que en $\operatorname{Dios}^{77}$. Luego no hay ni puede haber certeza acerca de la eternidad del mundo, según se desprende de este pasaje del capítulo VI del primer tratado. Se trata, en consecuencia, de algo opinable, en lo que insistirá el anónimo más adelante, en el cap. IV del segundo tratado: «pues en las cosas contrarias siempre se ha de seguir lo más verosímil y probable (verosimiliorem et probabliorem), pero es más verosímil y probable que el mundo sea eterno que creado. Luego, se ha de abrazar la opinión de la eternidad antes que la de la creación, que sólo se basa en la fe, mientras que la otra se sustenta en la razón natural y en el sentido común (ratione naturali et sensu communi), tal como se muestra y se aprueba por todos» ${ }^{78}$.

El anónimo se está refiriendo al relato de la creación del Génesis en el que, a su juicio, hay un nido de contradicciones. Pero lo fundamental es que en lo que llamamos libros sagrados, hallamos también el testimonio de Salomón, que en el Ecclesiastes (1, 4-10), aboga por la eternidad del mundo ${ }^{79} \mathrm{y}$ por un determinismo universal similar al que encontramos en la teoría de los partidarios del eterno

3 Tr, p. 167.

${ }^{74} \mathrm{Tr}$, p. 171: «Omnia nasci et decidere in terris».

75 Ibidem: «ab aliquo aeterno opifice proficisci, eundemque deum esse existimaverunt».

76 Ibidem.

77 Tr, p. 171: «probabilius multo et verisimilius est illam in mundo quam in deo credere et ponere».

$78 \mathrm{Tr}$, p. 265.

79 Ibidem: «Salomonis locus, ex quo haud dubie mundi aeternitas astruitur». 
retorno. El nibil sub sole novum salomoniano nos indica que aquello que se cree reciente ya ha sucedido en los siglos que nos han precedido ${ }^{80}$.

El anónimo afirma que la existencia del mundo resulta evidente a todos mientras que de Dios, tal como las religiones lo conciben, sólo podemos decir que es un ente inexistente y, si admitimos que existe, que es un ente de razón, una ficción de nuestra mente ${ }^{81}$. Más aún, Dios tiene menos entidad que la quimera, pues es un ente constituido por la nada. Dios carece de ser y ni siquiera puede atribuírsele alguna entidad, porque no existe ${ }^{82}$. Nadie lo vio, ni lo escuchó, ni lo concibió con su mente, porque es imposible percibir o conocer lo no ente. Con menor razón se puede atribuir la eternidad a lo que no existe.

El anónimo concluye su tratado refiriéndose a la disputa entre los filósofos y los teólogos paganos que sostenían que Dios y el mundo son coeternos ${ }^{83}$. Así, Aristóteles dijo que Dios y las inteligencias eran causa motriz y eterna del cielo eterno $^{84}$. También Platón, pasadas por alto sus bagatelas sobre el origen del mundo en el Timeo, sostuvo que el mundo era eterno en otro lugar ${ }^{85}$. Son muchos los filósofos que siendo realmente ateos, y sin explicar qué sean los dioses, por miedo a la plebe declaran abiertamente su existencia, con lo que contentan a la religión y al pueblo y, a la vez, a la razón, esto es, a los partidarios de la eternidad del mundo («deos enim non negantes, religioni et populis placebant; ortum mundi refelentes, rationi omnino consentiebant») ${ }^{86}$. Pero no es posible, según el anónimo, mantener las dos cosas a la vez. Entonces podemos preguntarnos: ¿por qué se declara seguidor de Aristóteles? En realidad, su aceptación del aristotelismo es compleja, pues además de negar que los cuerpos celestes estén causados por los elementos, rechaza, influido por Sexto Empírico y Alejandro de Afrodisias, que la materia, la forma sustancial (definida como «actus materiae) y la privación puedan ser principios, pues al ser eterno el mundo no puede derivarse de nada. Si la materia no está en ninguna parte y la forma es la actuación de la materia e

80 Ibidem: «iam enim praecesit in saeculis quae fuerunt ante nos».

${ }^{81}$ Tr, p. 172: «Deus vero, qualem ilum leges ponunt, nullum est ens, aut si est, nihil esse potest quam ens rationis et mentis nostrae figmentum, quod suum esse in intellectu tantum habet».

82 Ibidem: «Deus vero omnino caret ente nec etiam tamquam ens quoddam fingi potest, quia nullus est».

83 Tr, p. 336: «deum aeternum cum mundo aeterno».

${ }^{84}$ Ibidem: «Sic Aristoteles deum et intelligentias coeli aeterni causam motricem et aeternam dixit».

85 Ibidem.

86 Ibidem. 
inseparable de ella, y la privación un no ser, se está muy cerca de la creación ex nibilo ${ }^{87}$.

En realidad, la tesis de la coeternidad ha tenido siempre partidarios, tanto entre los seguidores de Aristóteles como entre los platónicos. Así, el obispo Zacarías de Mitilene (siglo VI) dice: «Si el mundo es incorruptible, es increado en el tiempo, porque siendo la causa demiúrgica eterna, también su obra es eterna en relación al tiempo" (aídiou gar ontos tou demiourgikou aitiou, aídion kata chronon tò demiourgema). De esa misma opinión es Filón de Alejandría, filósofo judío del siglo I d. C., seguidor de Moisés y autor del Peri aphtharsias tou kosmou (Sobre la incorruptibilidad del mundo), que el codex Laurentianus denomina erróneamente Peri tou kosmou genéseos y en la que su autor sostiene que el mundo es inengendrado e indestructible. Pero, al mismo tiempo, Filón admite que Dios es el creador eterno del modelo ideal del que participa el mundo físico observable. El mundo es increado en el tiempo y tiene un creador. Según Franz Cumont, Filón había pensado en una creación intemporal y, por ello, eterna. El mundo es creado porque no es necesario, dirá en cambio Avicena.

Casi todas las autoridades partidarias de la eternidad del mundo que cita el anónimo han sido examinadas en detalle por Filón, que se propone, como muchos otros en su tiempo, conciliar el pensamiento de Aristóteles y Platón. Según él, Aristóteles sostiene que el mundo es eterno e incorruptible, pero lo hace con un espíritu de piedad y religiosidad (eusebos kai hosios) ${ }^{88}$, en oposición a aquellos que creen que «no hay ninguna diferencia entre los objetos salidos de la mano del hombre y un tan grande dios visible (horatòn theón), que comprende el Sol, la Luna, en verdad, todo el panteón de los planetas y de las estrellas fijas». Siente pánico — añade - ante los que dicen que el mundo es perecedero (ton hapanta kosmon toi logoi katharirounton). Para Aristóteles las causas del cielo son la Inteligencia (Nous) y la Naturaleza ${ }^{89}$. Dios, motor inmóvil del mundo, siempre está en acto en tanto que es causa del movimiento y del orden del universo.

Según Filón, algunos sostienen que fueron los pitagóricos quienes inventaron esta teoría de la eternidad del mundo. El mismo dice que ha leído una obra de

87 Tr, pp. 198-199: «certum est materiam quae nullibi est, nec comprehendi potest, non posse principium esse. Forma vero substantialis quae est actus materiae, unum per se cum ipsa constituens, non magis principium esse quam materiam, utpote ab illa inseparabilis et absque illa, ut ita dicam, inseparabilis».

${ }^{88}$ FiLÓN (1969), 10.

89 Aristóteles, Metafísica, XI, 1065 b4. 
Ocelo de Lucania (Ocellus Lucanus), titulada La naturaleza del universo, en la que aquel sostiene que el mundo es increado e incorruptible (anolethron $)^{90}$. Sobre este personaje, que en realidad es un neopitagórico tardío, se creó toda una leyenda; hasta el punto de que, según Campanella, Aristóteles le robó su doctrina ${ }^{91}$.

El anónimo, aunque no dice que su fuente sea Filón, transcribe el siguiente pasaje de Ocelo: «El universo ni acabará jamás ni tuvo comienzo, pues siempre fue y será. Porque si estuviese sujeto al tiempo, no podría existir eternamente. Por tanto, ocurre que es inengendrado e imperecedero. Pues si alguien imagina que fue engendrado y tuvo nacimiento, no hallará en qué pueda descomponerse y dejar de ser, como quiera que existirá esa primera porción del universo de la que al principio fue engendrado y la última en la que se desvanecerá. Pero si el universo es engendrado, sería engendrado a la vez con todas sus partes y si muere es necesario que muera con todas ellas. Pero esto no puede ocurrir. En consecuencia el universo carece de principio y de fin y no puede ser de otra manera. A esto añade que todo aquello que tuvo comienzo ha de verse afectado por la disolución y debe sufrir dos cambios: uno de menor a mayor o de peor a mejor que se llama generación, otro de mayor a menor y de mejor a peor que se denomina muerte y disolución [...]. Pero este universo no nos muestra el menor indicio de eso: nunca lo vimos nacer, ni mejorar, ni hacerse más grande; ni desde luego empeorar o hacerse más pequeño, sino que siempre permanece uno y el mismo, igual y semejante a sí. Si ha de morir, es forzoso que se disuelva en algo que es ya o en nada. Si en algo que es ya, no puede ser, como quiera que así no habrá muerte de la universalidad de las cosas si la disolución es en lo que ya es. Porque lo que ya es o bien resulta ser el universo mismo o una parte de él. Tampoco puede disolverse en nada, porque no puede ser que lo que es proceda de la nada o acabe en la nada: luego el universo es eterno y en modo alguno está sujeto a destrucción» ${ }^{92}$.

Pero no sólo el mundo es eterno, sino también sus partes y, en consecuencia, el hombre, las plantas y los animales, que no tienen su origen de la tierra ${ }^{93}$, sino que, dado que el orden y la disposición del mundo existen desde siempre, es

90 Ocellus, De la naturaleza, I, 2.

91 T. Campanella, Metaphysica, XI, I, pars tertia: «Alii vero arbitantur mundum nullam habuisse originem, sed fuisse semper ut Ocellus Lucanus et Aristoteles, qui eius etiam verba furatus est». Cfr. Tr, p. 238, nota de los editores.

92 Tr, pp. 328-330.

93 Tr, p. 329: «nec vero, inquit, primum humani ortus initium, quaemadmodum nec caeterorum animalium, nec plantarum, terra ductum est». 
forzoso que también existan desde siempre aquellas cosas que están ordenadas y dispuestas en él.

Hay que tener en cuenta que el anónimo no siempre expresa lo que los autores por él citados sostienen realmente, como hemos tenido ocasión de comprobar a propósito del epicureísmo. Y esto es así también en el caso de Filón, por una doble razón, pues, en primer lugar, en De Aeternitate mundi, 150, dice: «Los argumentos que nosotros hemos recopilado concernientes a la incorruptibilidad del mundo, los hemos expuesto lo mejor que hemos podido. En cuanto a los desacuerdos relativos a cada uno de lo puntos, los expondremos en lo que sigue». El texto griego se interrumpe aquí, con lo que es difícil saber si se trata de un diálogo en el que el autor no estaría de acuerdo con las tesis expuestas anteriormente sobre la eternidad del mundo modo aristotelico y en la segunda parte sería crítico con ella. En segundo lugar, Filón es autor del De opificio mundi, donde, como judío, defiende la doctrina creacionista de Moisés y trata de armonizar, en la medida de lo posible, la doctrina de un dios creador con la de la eternidad de un mundo increado a partir de un análisis aritmológico, en el que la héxada juega el papel central, exenta de toda relación temporal. En este sentido, hay que decir que Filón fusiona el pensamiento platónico con el aristotélico. El mundo sería, como ya hemos dicho, para Aristóteles increado e incorruptible, mientras que para Platón sería creado e incorruptible. La tesis estoica de una corrupción total del universo supondría, como también hemos dicho ya, su desaparición en la nada absoluta, lo que resulta inaceptable para Filón.

Algunos, como Jacob Bernays, niegan que Filón sea el autor del De aeternitate, pues en el resto de sus obras se declara partidario de la creación; otros, en cambio, aseguran que se trata de una obra de juventud. Nada hay seguro sobre esto, pero sí parece, según Cumont ${ }^{94}$ y otros, que no hay contradicción entre lo que sostiene aquí y en el resto de la obra ${ }^{95}$. Según Cumont, no sería imposible admitir que para Filón Dios sea causa del mundo eterno, es decir, que el mundo sea creado desde toda la eternidad.

Platón, según la interpretación de Filón, afirma que el mundo es creado, pero incorruptible (geneton de kai aphtharton) por voluntad de su hacedor ${ }^{96}$, padre, creador y demiurgo (patéra men kai poieten kai demiourgon). El mundo

${ }^{94}$ F. Cumont (1891).

95 Filón (1969), introducción de R. Arnáldez, p. 24.

96 FiLÓN (1969), 13. 
es creado no tanto por haber tenido un comienzo de su génesis (ou toi labein geneseos archen), sino porque es imitación sensible derivada de un arquetipo y paradigma inteligible (ap'archetypou kai noetou paradeigmatos mímema aistheton). En este sentido, el mito del Timeo sería, como dice Plotino, expresión temporal de una realidad atemporal.

Son muchos los platónicos que sostienen que en el Timeo no se habla de un origen cronológico del mundo, aunque con fines didácticos se cuente un relato (mythos) donde se le atribuye un comienzo, sino de una relación causal, es decir, que el mundo depende de una causa diferente de él mismo; pero si el modelo es eternamente un modelo, el cosmos es eterno, porque es una copia de un modelo que existe eternamente (ei ara to paradeigma aionion paradeigma estin, aei estin ho kosmos, eikon tou aioniou ontos on paradeigmatos $)^{97}$.

Para Proclo (410-465) (no incluido por el anónimo en el listado de autoridades partidarias de la eternidad del mundo que ofrece en el capítulo VII del segundo tratado), autor de una obra titulada De Aeternitate mundi, también el mundo es eterno, pues el tiempo y los cielos son simultáneos, porque el tiempo es medida del movimiento de los cielos, que son cogenerados con el tiempo, es decir, no generados antes ni después ${ }^{98}$. Parece que este argumento iba dirigido contra Plutarco, que sostiene (De animae procreatione, 1017B) que el mundo no es ingenerado (ageneton) ni eterno (aídion), sino que ha tenido un comienzo y ha sido generado. Proclo propone dieciocho argumentos (conservados por Juan el Gramático, más conocido por Juan Filópono) para demostrar que este mundo es eterno porque es el efecto más divino producido por la más divina de las causas, el demiurgo o dios. Estos argumentos iban, según algunos, dirigidos contra los cristianos, partidarios de la no eternidad del mundo, tesis defendida abiertamente por Juan Filópono (490-570) en su obra De aeternitate mundi contra Proclum, donde sostiene que la teoría de Aristóteles sobre la imposibilidad de un infinito actual permite concluir que el mundo tiene un comienzo en el tiempo, ya que de lo contrario habría un infinito actual, esto es, un número infinito de años. Por consiguiente, el mundo no puede coexistir con Dios desde la eternidad ${ }^{99}$. El mundo es débil porque no es infinito, y necesariamente es perecedero y corrup-

\footnotetext{
${ }^{97}$ Proclo (2001), p. 40.

98 Ibidem, p. 57, argumento V.

99 Filópono (2005), p. 32.
} 
tible. Si fuera incorruptible, como piensan Platón y Proclo, sería porque Dios, que está fuera de él, lo conserva eternamente.

\section{Citas de autoridades partidarias de la eternidad del mundo}

También Tales sostuvo, según el anónimo, la eternidad del mundo, pues respondió a uno que le preguntó si fue anterior la noche al día: «la noche fue un día antes que el día». Es como preguntar, dice el anónimo, si fue antes el huevo o la gallina ${ }^{100}$.

Filolao, en su libro sobre el alma — dice el anónimo- escribió: «por tanto dura eternamente [el mundo] más allá de la muerte y de la destrucción toda vez que ni dentro de él hay una causa más fuerte que él ni fuera hay nada que pueda destruirlo. Por tanto este mundo existió desde la eternidad y dura hasta la eternidad, único, gobernable por un solo y nobilísimo padre [...]. En tercer lugar, se compone de ambas cosas, del mundo eternamente mudable y de la divinidad eternamente corriente; por tanto no sería impropio decir que el mundo es efecto de Dios y del nacimiento según la serie mudable de la naturaleza. Y aquel se comporta siempre del mismo modo, pero estas cosas en cambio nacen y mueren, si bien para devolver a su padre y hacedor nuevas formas» ${ }^{101}$. La divinidad eternamente corriente es la divinidad astral de la que en el tratado primero el anónimo dice que se deriva el término theós (el que corre, del verbo thein, correr). Los astros son, según el anónimo, los verdaderos dioses: «Igitur ex vi et significatione nominis perspectum compertumque habemus qui qualesque dii sint, sol nempe, luna, astra et coelum omne [...] nomen impositum illis fuit et currendi et vagandi per omne caeli spatium facultate [...]. Cum autem theos significet cursorem, recte dicetur: adorandus est cursor, pro adorandus es deus» ${ }^{102}$. Si para designar a Dios se utilizara otro término, este argumento del anónimo no tendría ningún valor. Gassendi dice que theos deriva de theasthai que significa mirar:« quod videret universa, et provideret omnia» ${ }^{103}$.

Aristeo, en el libro Sobre la armonía, también sostiene la eternidad del mundo y del principio: «ya que el principio en cuanto tal está antes que todo y carece de

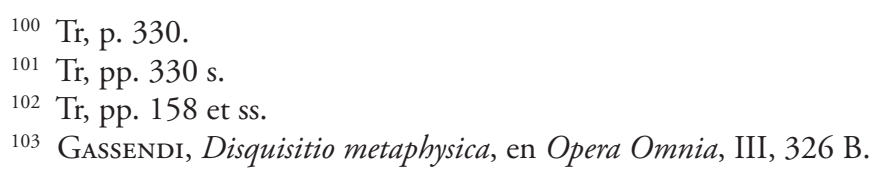


nacimiento y es perfecto [...], está claro que carece por sí mismo de movimiento y es eterno [...]. Dado que el autor del universo ni muere ni se fatiga, es claro que el mundo es eterno, porque si tuviera principio el motor se pararía alguna vez cansado y si eso ocurriera, él por su parte tendría como mortal un fin del movimiento y el universo tendría nacimiento. Por tanto, es necesario eliminar el nacimiento de las cosas o engendrar de la nada un ente o admitir que el mundo es eterno» ${ }^{104}$.

El anónimo cita, según hemos expuesto más arriba, el De aeternitate mundi de Filón, aunque bajo el título: de non interituro mundo, ${ }^{105}$ como defensor de la eternidad del mundo y contrario, por tanto, a la creación. También expone la doctrina de Critolao, defensor de la tesis de que el mundo es eterno porque tiene en sí mismo la causa de su existencia. El mundo — dice- no es ni generado ni destructible, porque sólo hay dos causas para que algo perezca: una interna, como la herrumbre que consume al hierro o al bronce, y otra externa, como cuando un incendio destruye una casa o la ciudad entera, o cuando un animal muere de enfermedad o degollado o ahorcado. Pero fuera del mundo no hay nada, ya que todo sirvió y se reunió para completarlo. Es, por tanto, uno, entero y carente de vejez. Como ninguna parte está separada de él, sino que todo está dentro de él, nada externo lo puede destruir, pues si hubiera una causa externa, sería inane o una naturaleza impasible, incapaz de actuar o padecer. Tampoco es destructible por una causa interior, ya que ello exigiría que una parte fuese más poderosa que el todo, lo que sería absurdo. El mundo supera con su increíble fuerza las partes que agita y mueve, mientras que él no es movido ni agitado por ninguna de ellas. Luego, el mundo no ha tenido comienzo ni puede tener fin. Lo mismo que no puede ocurrir que de la nada surja algo, tampoco es creíble que aquello que es sea eliminado o muera del todo. Por tanto, el mundo es eterno "porque así como lo que no tiene nacimiento tampoco puede tener muerte, sino que es eterno, igualmente, por la razón contraria, lo que no puede sufrir muerte, en modo alguno pudo tener nacimiento, sino que es eterno» ${ }^{106}$.

Finalmente, Plinio Segundo, que tanto influyó en el naturalismo renacentista, además de concebir a Dios como potencia de la naturaleza («naturae potentiam id esse quod deum vocamus»), también afirma que el mundo es eterno: «El mundo y todo aquello que se decidió llamar con otro nombre, cielo, cuyos

\footnotetext{
104 Tr, p. 331.

105 Ibidem.

106 Tr, pp. 333 ss.
} 
giros todo lo gobiernan, es lógico que sea considerado una divinidad (numen), eterna, inmensa, ni engendrada, ni perecedera. Indagar sus entrańas ni le interesa al hombre ni está al alcance de su mente; es sagrado, eterno, inmenso, todo en todo; más todavía, él es un todo, infinito y semejante a lo finito, abarcándolo todo en sí por fuera y por dentro, obra de la naturaleza y la naturaleza misma» ${ }^{107}$. El anónimo, a pesar de su ateísmo, parece profesar este tipo de panteísmo: «el mundo es eterno [...] luego se ha de declarar que Dios no existe, a no ser que quisiéramos entender por Dios la naturaleza misma, como han pensado algunos. En ese caso se ha de confesar que existe Dios, pero no como lo conciben las leyes y los teólogos» ${ }^{108}$. Precedentes de esta opinión los hallamos en muchos filósofos estoicos o en Giordano Bruno: «vel nihil est natura, vel est divina potentia materiam exagitans, impressusque omnibus ordo perpetuus» ${ }^{109}$.

Entre los autores modernos, el anónimo cita a Pomponazzi, Cardano y Vanini. Pomponazzi, siguiendo los principios de Aristóteles ${ }^{110}$, dice que tanto el mundo como el hombre son eternos, ya que «el sol y el hombre generan al hombre» ${ }^{111}$. También Cardano (De rerum varietate, 8,46 ) dice que este mundo es tal que en todas partes tuvo pobladores autóctonos, y que como no los empujó la superpoblación a emigrar y buscar nuevos asentamientos, es «necesario que el género humano se base en su sustancia propia, no en un origen ${ }^{112}$. También sostiene la eternidad del mar a partir de la eternidad de las aguas y de la salinidad. Para Vanini, «solo la religión le mueve a pensar que el mar se acabará. Pues ¿qué fuerza podría acabar con tan enorme masa de agua? El Sol no, ya que devuelve al agua lo que toma, pues aunque saca agua del mar se la devuelve de nuevo agradecido. El fuego tampoco, al menos este nuestro, pues es pequeñísimo y no dudo de que todos los fuegos que hay sobre la tierra pueden ser apagados con el agua de un solo río; tampoco el fantástico fuego elemental, pues si existiese no se movería de su sitio que dicen que son las alturas. Como el agua busca la parte baja, siempre estará segura de ese enemigo suyo» ${ }^{113}$.

107 Tr, p. 333.

108 Tr, pp. 92-93: «At mundus est aeternus [...]; deos igitur non esse existimandum est, nisi fortasse per deum naturam ipsam inteligere voluerimus, ut quidam arbitrati sunt. Tunc autem confitendum erit esse quidem deum, sed non qualem illum leges et theologi fingunt».

109 Bruno, De immenso et innumerabilibus, citado en nota de los editores a Tr .p. 93.

110 Aristóteles, Física, II, 2, 194 b14.

111 Pomponazzi (2010), cap. VIII, p. 57; Tr, p. 333.

112 Tr, pp. 333.

113 Tr, p. 334. 
De nuevo retorna el anónimo a los filósofos antiguos: Ferécides, Anaximandro, Alcmeón, Jenófanes, Parménides, Meliso. Todos los que hacen el mundo eterno suponen, según Stobeo, que hay unos ciclos temporales al cabo de los cuales todo vuelve a ser lo mismo, manteniéndose así la organización del mundo. En conclusión, según el anónimo, «todos los que han conseguido algo con sus razonamientos sobre la naturaleza, han afirmado siempre la eternidad del mundo» ${ }^{114}$.

\section{La eternidad del hombre}

El anónimo retoma la tesis de Aristóteles, Averroes y Siger de Brabante de que el mundo y el hombre son eternos: «no hubo un primer hombre ni habrá un último, sino que habrá siempre la generación de un hombre a partir del semen de otro hombre» ${ }^{15}$. Una vez que ha demostrado que el mundo es eterno y que los dioses son una ficción ${ }^{116}$, se pregunta el anónimo si también la especie humana es eterna. Su respuesta es que las plantas y los animales son corruptibles porque son generables, aunque sus especies es claro que se derivan ab aeterno, aunque añade: «no afirmaría yo que duren eternamente, ya que están sujetas a corrupción y muerte» ${ }^{117}$.

Si hubiera una catástrofe, las serpientes, los ratones, las orugas y otros insectos, nacidos de la podredumbre, resurgirían como los otros que se han extinguido, mientras el Sol dé calor a la tierra, pero los que se producen del semen es posible que perezcan, con lo que la osada soberbia del hombre es preciso que se precipite en las profundidades de la humillación, pues se cree superior a las demás criaturas, cuando es la más vil de ellas («cum infra alia quae vilissima putat esse deprimere omnino debeat») $)^{118}$.

De todos modos, el anónimo no considera probable que la raza humana, igual que otros animales perfectos, se extinga por una vicisitud natural, hasta el punto de que no quede ninguna pareja humana que genere a otros, como ya sucedió muchas veces ${ }^{119}$. Es más probable que sobrevivan los insectos (insecta) que los animales más acabados (perfecta), dado que se engendran a partir de la

114 Tr, p. 335.

115 Tr, p. 177, cita de los editores.

116 Tr, p. 176: «mundum esse aeternum constet et deos esse figmentum».

117 Ibidem.

118 Tr., p. 177.

119 Tr, p. 178. 
materia permanente y eterna: del barro y del Sol. Los que se engendran a partir de la simiente (semen) duran hasta ahora sin interrupción, aunque es posible que perezcan por completo ${ }^{120}$. En efecto, para que sea engendrado un hombre hace falta otro hombre que de mil modos puede perecer y ser aniquilado, y cuando no quede ninguno que pueda generar a otro, la especie quedará extinguida y agotada. Es verosímil, sin embargo, que existan ab aeterno y duren in aeternum ${ }^{121}$. En cuanto a la eternidad, unos la niegan, otros la afirman, otros dicen que sólo son eternas las cosas permanentes (dotadas de movimiento eterno y circular), pero no las sucesivas, todas o algunas. Por sucesivas se entiende las generaciones ab aeterno, como dice Aristóteles: "Cada hombre nació de otro anterior a él, o bien, todos los hombres han sido engendrados del mismo modo, a saber, por un macho y una hembra que existen ab aeterno» ${ }^{122}$.

También Censorino dice que hay, por un lado, partidarios de la opinión de que los hombres siempre han existido y se generan unos a partir de los otros, y quienes, por otro, sostienen que hubo un tiempo en que no había hombres, sino que surgieron en un momento dado de modo natural. De la primera opinión son Pitágoras, Ocelo, Arquitas, Platón, Jenócrates, Dicearco, Aristóteles, Teofrasto y otros aristotélicos que ponen como ejemplo el huevo y la gallina. Hay una rueda (orbem) de generadores y nacientes, en la que el comienzo de cada ser engendrado parece al mismo tiempo un final. Por otro lado, están los que dicen que los hombres fueron hechos por Dios o la naturaleza (divinitus naturave) y que su origen proviene de la putrefacción y el barro (ex putredine et limo); entre los partidarios de esta opinión hay que enumerar a Avicena, Diodoro Sículo y Pico de la Mirandola, entre otros. El anónimo admite, como los filósofos de la época, la generación espontánea de la vida: de la podredumbre y del barro surgen los seres vivos inferiores.

\section{Conclusión}

Después de haber examinado la larga exposición del anónimo autor del Theophrastus redivivus de los argumentos de los ateos sobre la eternidad del mundo y del hombre, creemos necesario hacer un balance de su aportación. Si fuera, como ha dicho en el prólogo, un cristiano fiel a Roma y no suscribiese ninguna

$120 \mathrm{Tr}$, p. 177: «quae etsi nunc permanece videntur, eas tamen penitus interire possibile est».

121 Tr, p. 178.

122 Tr, p. 183. 
de las herejías de las que reconoce que está su libro repleto, no se entiende el ardor con el que defiende los principios del materialismo y del ateísmo. Es posible, como se ha sugerido, que se parapete bajo el escudo del cristianismo para evitar la censura, aunque no me parece eso verosímil, pues ningún censor daría su aprobación a la publicación de una obra de estas características. Es posible, como dice Gregory ${ }^{123}$, que se trate de un desafío (sfida) a los teólogos, a los que vendría a decir: Aquí están reunidos todos los argumentos de los ateos, rebatidlos si podéis.

En cualquier caso, el libro, muy bien escrito y perfectamente sistemático, a pesar de ser un mosaico interminable de citas, guarda un hilo conductor que lo convierte en una verdadera enciclopedia del ateísmo, lo que no quiere decir que la selección habilidosa que, en ocasiones, hace de los textos de los filósofos que cita, no sea tendenciosa. Su propósito es continuar con la tarea crítica de los libertinos, adornada con innumerables testimonios de la filosofía antigua, y confrontarla con la religión y la moral cristianas. A ese fin responde la constante referencia a Epicuro, Lucrecio, Sexto Empírico, redescubiertos y, en cierta medida, reinterpretados por los autores del Renacimiento. Su pensamiento, sin embargo, es autónomo y va más allá de lo que dicen sus fuentes inmediatas (Bodin, Pomponazzi, Cardano o Vanini). Para probar esto, basta tener en cuenta su rechazo de la demonología, de la brujería, de la astrología; en fin, de todo ese mundo mágico presente en algunas de sus fuentes. Es un espíritu libre que no presta más atención a lo que dicen los demás que a lo que él mismo piensa.

Es verdad que sorprende que no tenga para nada en cuenta la filosofía y la ciencia de su época (Descartes, Gassendi, Hobbes, Galileo, etc.) Nada hay en él, salvo alguna referencia a Cyrano, Patin, Saumaise y Fabrot, que nos permita afirmar que escribe en 1659. Quizás se crea liberado de esa obligación porque lo que se propone es hacer una historia del ateísmo. Si no cita a Gassendi, a pesar de su interés por Epicuro, quizás se deba a que no está, en caso de conocer su obra, de acuerdo con su intento de cristianizarlo de algún modo. Tampoco cita a La Mothe le Vayer, aunque ambos sostienen puntos de vista muy próximos. Hay, con todo, entre ellos una profunda diferencia. La Mothe le Vayer, cuando expone doctrinas contrarias a la religión, siempre deja fuera de su crítica a la religión cristiana. En el anónimo, en cambio, los argumentos de los filósofos contra la religión pagana son aplicables a la cristiana. Mientras los teólogos sigan basándose solo en la fe y la auctoritas, válidas exclusivamente para los creyentes, y no

123 Gregory (1979), p. 18 
respondan a sus adversarios con argumentos basados en la ratio vera et naturalis, nunca lograrán, a su juicio, que sus fabulaciones convenzan a los sabios.

Los argumentos de los filósofos partidarios de la eternidad del mundo y del hombre, exhaustivamente expuestos y analizados por el anónimo, son un medio indirecto de confirmar que no existe Dios, pero, como él mismo afirma de modo explícito, se mueven en el terreno de la probabilidad ${ }^{124}$ : es más probable y verosímil poner la eternidad en el mundo que en Dios; es más probable sostener que el mundo es eterno que afirmar que ha sido creado ${ }^{125}$. Incluso dice que no está seguro de que una catástrofe no extinga a la humanidad ${ }^{126}$. Si la filosofía no logra alcanzar una certeza absoluta sobre estos temas, la opinión contraria (la de los cristianos) está obligada a encontrar argumentos racionales para inclinar la balanza de su lado, cosa que hasta ahora, según el anónimo, no ha logrado porque se basa en la fe y da por demostrado lo que debe demostrar con argumentos racionales: que Dios existe. Pero este supuesto, según dice el anónimo en el prólogo, ha sido aniquilado por la filosofía («fundamentum a philosophia subversum et dirutum, nempe Deum esse»). Si la única filosofía posible es la que niega la existencia de Dios, ¿por qué se declara cristiano? Si no se está burlando del lector, ¿cree en la posibilidad de otra filosofía diferente y superior a la de los ateos? Sólo así se entendería que se declarase cristiano. Si, por el contrario, es un ateo y se mofa de los teólogos cristianos, una vez cree demostrado que no existe Dios, es evidente que no es creador, que la religión no ha sido revelada y que el alma es mortal, etc., con lo que podía haberse ahorrado el segundo tratado y el tercero y todos los demás. En realidad, él mismo lo reconoce, pero dice que su propósito es escribir, como Teofrasto de Ereso, una historia de lo que se dicho de los dioses.

Su afirmación de que todos los filósofos son ateos, incluidos Platón y Aristóteles, como es obvio, es muy discutible. Naturalmente, hay que explicitar qué hay que entender por Dios y qué entiende él en concreto. En el capítulo cuarto del primer tratado, como ya hemos dicho, afirma que si por Dios se entiende la Naturaleza, como algunos han pensado, habrá que admitir que Dios existe, aunque no es como las leyes y los teólogos lo representan: «deos igitur non esse existimandum est, nisi fortasse per deum naturam ipsam intelligere voluerimus, ut quidam arbitrati sunt. Tunc autem confitendum erit esse quidem deum, sed

124 Tr, p. 171.

125 Tr, p. 265.

126 Tr, p. 177. 
non qualem illum leges et theologi fingunt». El que escribe esto no es realmente ateo, aunque desde luego tampoco puede ser un cristiano. Lo que está negando es que haya un Dios distinto de la Naturaleza, es decir, del mundo: «natura enim mundus totus est». Si Dios se distingue de Naturaleza, es necesario que haya sido engendrado por ella, como todas las demás cosas («si alius est deus quam natura, necesse est ut eum illa genuerit» ${ }^{127}$. Si aceptamos que el panteísmo no es un ateísmo, lo que se niega es la existencia de un Dios distinto del mundo, creador y providente, tal como lo han concebido los teólogos judíos, cristianos y mahometanos.

Ya hemos visto que una de las corrientes filosóficas antiguas más presentes en su libro es la epicúrea, pero Epicuro, a pesar a de lo que diga el anónimo y muchos otros anteriores a él, admite la existencia de los dioses y niega la eternidad del mundo ¿Cómo podemos aceptar sin más su afirmación de que la filosofía ha subvertido y destruido la existencia de Dios? ¿No es Epicuro un filósofo?

\section{Bibliografía}

Busson (1948). H. Busson, La religion des classiques (1660-1685), P. U. F., París.

Cumont (1891). Franz Cumont, Philonis de Aeternitate mundi, Berlin.

Filón (1969). Philon d'Alexandrie, De aeternitate mundi, introducción y notas de R. Arnaldez, traducción de J. Pouilloux, Cerf, Paris.

Filópono (2005). John Philoponus, Against Proclus on the Eternity of the World, traducción de Michael Share, Duckworth, Londres.

Gregory (1979). Tullio Gregory, Teophrastus redivivus. Erudizione e ateismo nel Seicento, Morano, Napoli.

Lenoble (1971). Robert Lenoble, Mersenne ou la naissance du mécanisme, Vrin, Paris.

Lucrecio (1976). Lucrecio, De la naturaleza. De rerum natura, edición y traducción de Eduardo Valentí Fiol, Bosch, Barcelona.

Mersenne (1624). Marin Mersenne, L impiété des deistes, athées et libertins de ce temps, Paris.

Nifo (2009). Agostino Nifo, L 'immortalità dell'anima: Contro Pomponazzi, introducción, texto latino y notas de J. M. García Valverde; traducción de F. P. Raimondi, Nino Aragno, Turín.

127 Tr, pp. 92-93. 
Pintard (1941). Réné Pintard, Le libertinage érudit dans la première moitié du XVIIe siècle, 2 vols., Boivin, París.

Pomponazzi (2010). Pietro Pomponazzi, Tratado sobre la inmortalidad del alma, traducción de J. M. García Valverde, Tecnos, Madrid.

Proclo (2001). Proclus, On the Eternity of the world, ed. de Helen S. Lang y A. D. Macro. University of California Press, Berkeley-Los Angeles.

Rodríguez Donís (2008). Marcelino Rodríguez Donís, Materialismo y ateísmo. La Filosofía de un libertino del siglo XVII. Secretariado de Publicaciones de la Universidad de Sevilla, Sevilla.

SpINk (1937). J. S. Spink, "La diffusion des idées matérialistes et antireligieuses au début du XVIII siècle: le Theophrastus redivivus», Revue d'histoire littéraire de la France, pp. 246-255.

Theophrastus Redivivus (1981). Theophrastus redivivus, edición primera y crítica al cuidado de di G. Canziani y G. Paganini, 2 vols., La Nuova Italia Editrice, Florencia.

WADE (1938). Ira O. Wade. Clandestine organization and diffusion of philosophic ideas in France from 1700 to 1750 . Prnceton University Press, Princeton.

Recibido: $17 / 12 / 2013$

Aceptado: 13/01/2014 